\title{
Women, Football and History: International Perspectives
}

\section{Jean Williams and Rob Hess}

The quarrels of popes and kings, with wars and pestilences in every page; the men all so good for nothing and hardly any women at all - it is very tiresome.

Jane Austen ${ }^{1}$

The musings of Georgian novelist Jane Austen on the male domination of history apply equally well to the world of sport. As a general rule, the sporting achievements of women are routinely trivialized, ridiculed or simply ignored by a media fixated on male sport. Governing bodies are little better, whatever their recent rhetoric of inclusivity. In 1970 FIFA conducted a survey to its one hundred and thirty nine constituent affiliated national associations. This produced ninety responses, only twelve of which replied in favor of endorsing the women's game. ${ }^{2}$ While Simon Kuper and Stefan Szymanski generalize rather over-broadly that 'big, rich' nations win in women's soccer (given the relative success of the Norwegian women's national team), it is clear that poorer nations tend not to support their female players at all. ${ }^{3}$

Given that the same general pattern is probably true of other women's football codes, it remains the case that: 'There is more to women's relationship with football than academics

\footnotetext{
${ }^{1}$ Jane Austen, cited in David Whyte, The Three Marriages: Reimagining Work, Self and Relationship (New York: Riverhead Books, 2009), 217.

${ }^{2}$ FIFA, Minutes of the First UEFA Women's Football Conference, March 22, 1972 (Zurich: FIFA Archive), pp. 21-22.

3 Jean Williams and Megan Chawansky, 'Namibia’s Brave Gladiators: Gendering the Sport and Development Nexus From the $19982^{\text {nd }}$ World Women and Sport Conference to the 2011 Women's World Cup,' in Michelle Sykes and John Bale (eds.) Women's Sport in Africa, a Special Edition of Sport in Society: Cultures, Commerce, Media, Politics, 17:4 (December 2013), pp. 550-562.
} 
have so far described', and there is still much to be uncovered, documented, and written about when it comes to women and the football codes. ${ }^{4}$ This provides the starting point for this collection, but there are now a range of academics who have engaged critically with this historical neglect of women across a range of sports. Lois Bryson is amongst the commentators who have shown that 'sport is one of the most significant areas for forming and maintaining masculine and feminine identity, and this in turn underpins the reproduction of male dominance'. ${ }^{5}$ Bryson contends that the principal sports in which (Australian) men have historically participated, namely football and cricket, are team sports, and she maintains that 'this embodies an additional element - that of a gender solidarity which of its nature excludes women'. ${ }^{6}$ However, emerging evidence now indicates the active engagement of women in modern codified football, from the very beginnings of systematised matches of Association Football. For instance, the popular historian Chris Unger, has an image from Harper's Bazaar on his website dated August 1869 showing young women in fashionable dress playing what appears to be soccer, although it is unclear whether this was an organized match or evidence of a "kick-about" or "pick-up" game.

The accepted conventions and nomenclature in sport date from the history of governing bodies created by young men who saw their main focus the sporting camaraderie of other young men. Underpinning the arguments of several contributors to this collection, the issue is highlighted elsewhere by two scholars of South African sport. André Odendaal in his exploration of women's cricket in South Africa, attests that female cricketers in South Africa have been actively involved in the game for more than a century and have played a part in

\footnotetext{
${ }^{4}$ Williams, A Game for Rough Girls?, 4.

${ }^{5}$ Lois Bryson, 'Gender', in Wray Vamplew, Katherine Moore, John O'Hara, Richard Cashman and Ian Jobling (eds), The Oxford Companion to Australian Sport, Revised Second Edition (Melbourne: Oxford University Press, 1997), 179.

${ }^{6}$ Bryson, 'Gender', 179-180.

${ }^{7}$ Anonymous, "The Girls of The Period, Playing at Ball," Harper's Bazaar, August 1869, in Chris Unger The History of Women's Football http://thehistoryofwomensfootball.com/1800s.html accessed 6 February 2015.
} 
'developing fascinating cricket subcultures'. ${ }^{8}$ However, he claims that they are faced by what the historian Colin Bundy has called 'history as negation'. 'As Odendaal laments, 'Women's cricket in this country is virtually invisible. People know little about it. So it is assumed women don't play cricket and have no real cricket history worth talking about'. ${ }^{10}$ In fact, prior to the Great War, women who did play cricket in South Africa had to do so 'out of sight', and 'in a separate world where their participation was not experienced as a direct challenge to male control sporting space and the masculine imperial ideology cricket had become drenched in'. ${ }^{11}$

Though this is useful, the history of women's soccer is somewhat different than cricket, because it was so controversial and community-based in Britain and then across Europe and to the United States. The first home international women's association football match took place on the 9 May 1881 when a team calling themselves England played a side named Scotland at Easter Road, Edinburgh. Scotland won 3-0, and although the teams played at least seven matches, information remains patchy. Edinburgh versus Grimsby scheduled a match in 1887, leading the English port to claim the first women's football club side, though working women in Sunderland also played.

A London-based team, the British Ladies Football Club (BLFC), was founded in 1895 with Secretary Nettie Honeyball, (a poetic pseudonym). Aristocrat and explorer Lady Florence Dixie agreed to act as President. The club continued for over 100 matches all over Britain with over twenty more as Mrs. Graham's Eleven. After what appears to be a hiatus, the paying crowds for women's football grew rapidly between 1917 and 1921 in Britain,

\footnotetext{
${ }^{8}$ André Odendaal, "Neither Cricketers Nor Ladies"; Towards a History of Women and Cricket in South Africa, 1860s-2000s', The International Journal of the History of Sport 28, no. 1 (2011), 116.

${ }^{9}$ Bundy, cited in, Odendaal, "Neither Cricketers Nor Ladies"”, 116.

${ }^{10}$ Odendaal, "Neither Cricketers Nor Ladies", 116.

${ }^{11}$ Odendaal, "Neither Cricketers Nor Ladies", 122.
} 
although the economic conditions were not favourable, largely as a result of the changing nature of women's work but also down to a larger sense of social collective action on behalf of a paying public. ${ }^{12}$ In March 1921 The Lancashire Daily Post covered an international 9-0 England win against a Scotland side at Celtic Park. Many of the England team were Dick, Kerr Ladies players and the Preston team had played again in an 8-1 win the previous Saturday at Coventry City in front of 27,000 with gate receipts $£ 1,622 .{ }^{13}$

Rather suddenly, the FA "banned" women's teams from playing football on League and Association-affiliated grounds from 5 December 1921. The FA ruled that too much money had been absorbed in expenses in charitable games and the football was "unsuitable" for women because it was too vigorous. ${ }^{14}$ The FA ban remained and was enforced periodically (especially in 1946 and 1949) until informally rescinded following the intervention of FIFA in 1969. The ban shaped soccer as a masculine sport in one of the most important football nations in the world.

There are precise historical moments of negating women's interest therefore that other team sports like cricket do not share. But all football codes are perceived as essentially masculine in nature and are constantly reconstructed as so, even today. Karen Espelund, a respected Norwegian player and former General Secretary of the Norwegian Football Association was "co-opted" on to the executive board of the European Football Confederation (UEFA) in

\footnotetext{
${ }^{12}$ Alethea Melling, "'Ray of the Rovers': The Working Class Heroine in Popular Football Fiction 1915-25," The International Journal of The History of Sport 15: 1 (April 1998), pp. 97-122; Alethea Melling, "Cultural Differentiation, Shared Aspiration: The Entente Cordiale of International Ladies' Football 1920-45" The European Sports History Review 1:1 (August 1999), pp. 27-53.

${ }^{13}$ Anon. “Dick, Kerr's Still Winning," The Lancashire Daily Post, March 2, 1921, p. 4.

${ }^{14}$ Anon. "Health Giving Kicks-Girl Footballer Who Scored 368 Goals Saw Doctor Only Once," The Daily Mirror, December 9, 1921 p. 7.
} 
2011 it was heralded an important first by the governing bodies and the media. ${ }^{15}$ In 2012 Lydia Nsekera, the President of the Burundi Football Association became the first woman coopted member of the FIFA Executive Committee. But what kind of firsts are these? We know that women had pioneered important aspects of football back as far as 1881 and had sought to administer the sport in high profile leagues since at least 1895.

When 'history as negation' is combined with 'heteronormativity' (an all-encompassing belief that there are only two sexes and that each has inexorable gender roles), participation by women in sport, and recognition of that participation, becomes constrained at best. Mari Haugaa Engh, in her article on women's soccer in South Africa, echoes Bryson by claiming that 'Sport is a social institution that perpetuates gendered ideologies in the wider society through appealing to discourses of the naturalness of men's privilege and domination in society'. ${ }^{16}$ This is not just an issue in South Africa, or in soccer codes but has a broad uneven application across several national contexts as Elsey and Nadal have shown. ${ }^{17}$ Men's sport is often normalised through language as football, or soccer, with women's versions always modified by a gendered descriptor. The same goes for sport, and women's sport, more generally.

Issues associated with nomenclature can also be confusing in other ways. For example, as Melissa C. Wiser explains, the use of the term 'lacrosse' in the USA to refer to both men's and women's versions of the game is misleading: 'In actuality, men's lacrosse and women's

\footnotetext{
15 "UEFA Executive Committee June Meeting," UEFA.com the official website for European football, June 17, 2011 www.uefa.com/uefa/aboutuefa/organisation/executivecommittee accessed 27 September 2014.

${ }^{16}$ Mari Haugaa Engh, 'Tackling Feminity: The Heterosexual Paradigm and Women's Soccer in South Africa, The International Journal of the History of Sport 28, no. 1 (2011), 137.

${ }^{17}$ Brenda Elsey and Joshua Nadel 'Marimachos*: On Women's Football in Latin America' The Football Scholars Forum 6 December 2014 http://footballscholars.org/tag/brenda-elsey/ accessed 28 March 2016; Brenda Elsey Citizens and Sportsmen: Fútbol and Politics in Twentieth-Century Chile (Austin: University of Texas Press, 2011).
} 
lacrosse are different sports in terms of the history, the rules and course of play. Nevertheless they share a singular name'. ${ }^{18}$ Importantly, though, she notes that 'the historical relationship between men's lacrosse and women's lacrosse is crucial to an understanding of how the women's sport should continue and how that continuation correlates with societal gender relations'. ${ }^{19}$ Revealingly, Wiser also outlines how the notion that women's lacrosse is the purer game, 'or more true to the original Native American stick and ball games', has been used to 're-establish' the position of women's lacrosse in response to wider debates that have tried to 'situate the women's sport as inferior to the men's' ${ }^{20}$

Engh's investigation of the development of women's soccer in South Africa is also instructive because she draws on the work of Martha Saavedra, who argues that a key obstacle to the progress of women's soccer is the extreme popularity of the men's game. As Saavvedra points out, the pervasiveness of the men's game has meant that 'women's football has been met with scepticism, neglect and sometimes outright hostility'. ${ }^{21}$ In this context, notes Engh, 'For many clubs the fear is that women's football will take publicity and resources away from the male clubs and teams that are struggling with material inequalities and lack of sponsorships'. ${ }^{22}$ But Engh remains hopeful, and bold. As she states:

\footnotetext{
Women soccer players, through engaging in a sport that is deemed by many to be a masculine sport, are constantly engaged in challenging notions of female appropriateness and female athleticism. Through their participation they are destabilising notions about gender roles, as well as notions about the physical and

${ }^{18}$ Melissa C. Wiser, 'Lacrosse History, a History of One Sport or Two? A Comparative Analysis of Men's Lacrosse and Women's Lacrosse in the United States', The International Journal of the History of Sport 31, no. 13 (2014), 1656.

${ }^{19}$ Ibid., 1658.

${ }^{20}$ Ibid., 1665

${ }^{21}$ Martha Saavedra, cited in Engh, 'Tackling Feminity', 140.

${ }^{22}$ Engh, 'Tackling Feminity', 140.
} 
natural difference between men and women, masculinity and femininity. Moreover, their participation in this beautiful game allows them a sense of bodily ownership, strength and control that conventional feminine ideals and sports simply cannot offer. $^{23}$

Engh declines to posit that women's soccer will inevitably alter unequal gender power relations. However, she does believe that 'through women's soccer the notions of "what men can do" and "what women can do" and the associated gender roles and stereotypes are challenged and can be reconstructed in more equitable ways' ${ }^{24}$

An important lesson from these writers and others is the value of identifying less well known experiences of women's organized physical activities, particularly in different temporal and geographic contexts, that help to either confirm or challenge preconceived notions of the development of female sport. In this vein, the papers in this collection consider women and football from different, if not unusual, perspectives. Accordingly, it should be acknowledged that there is now a healthy academic literature on which the papers can draw. These include monographs (or edited collections) by Sue Lopez, ${ }^{25}$ Jean Williams, ${ }^{26}$ Jonathan Magee et al., ${ }^{27}$ James Lee, ${ }^{28}$ and Jayne Caudwell, ${ }^{29}$ not to mention several popular books on the Dick, Kerr's

\footnotetext{
${ }^{23}$ Engh, 'Tackling Feminity', 149.

${ }^{24}$ Engh, 'Tackling Feminity', 149.

${ }^{25}$ Sue Lopez, Women on the Ball: A Guide to Women's Football (London: Scarlet Press, 1997).

${ }^{26}$ Jean Williams, A Game for Rough Girls? A History of Women's Football in Britain (London: Routledge, 2003); Jean Williams, A Beautiful Game: International Perspectives on Women's Football (London: Berg, 2007).

${ }^{27}$ Jonathan Magee, Jayne Caudwell, Katie Liston, and Sheila Scraton (eds), Women, Football and Europe: Histories, Equity and Experiences (Oxford: Meyer \& Meyer Sport, 2007).

${ }^{28}$ James Lee, The Lady Footballers: Struggling to Play in Victorian Britain (London: Routledge, 2008).

${ }^{29}$ Jayne Caudwell (ed.), Women's Football in the United Kingdom (London: Routledge, 2012).
} 
women's team. ${ }^{30}$ Chapters in edited collections and journal articles include works by Gertrud Pfister $^{31}$ along with material in journals such as Football Studies. ${ }^{32}$

It is now more widely accepted that more academic studies should have a transnational and cross-code focus. Female elite player migration has been covered by a research monograph Globalising Women Football: Migration and Professionalisation 1971-2011 and a recent edited collection by Agergaard and Tiesler Women, Soccer and Transnational Migration. ${ }^{33}$ Trends relating to player migration in football's global gendered labour markets are now being defined. Firstly, studies have analysed the growing transnational migration of female professional players and related skilled specialisms such as coaching, administration and so on. Secondly, we are beginning to understand the 'push' and 'pull' factors involved in female professional player migration. In addition, en edited work by Kim Tofoletti and Peter Mewett and publications by Stacey Pope have analysed the multiple roles and identities of female fans of sport; including those of women's sport. ${ }^{34}$ This bodes well for further cross-code research.

\footnotetext{
${ }^{30}$ D.J. Williamson, Belles of the Ball (Devon: R. \& D. Associates, 1991); G. J. Newsham, 'In a League of Their Own': Dick, Kerr Ladies Football Club, 1917-1965 (Corley, UK: Pride of Place Publishing, 1994); Barbara Jacobs, The Dick, Kerr's Ladies (London: Robinson, 2004).

${ }^{31}$ Gertrud Pfister, 'Reconstructing Femininity and Masculinity in Sport - Women and Football in Germany and France During the Inter-War Years', in Ken Hardman and Joy Standeven (eds), Cultural Diversity and Congruence in Physical Education and Sport (Aachen: Meyer and Meyer Sport, 1998), 81-100; Gertrud Pfister, Kari Fasting, Sheila Scraton and Benilde Vazquez, 'Women and Football - A Contradiction? The Beginnings of Women's Football in Four European Countries', in Sheila Scraton and Anne Flintoff (eds), Gender and Sport: A Reader (London: Routledge, 2002), 66-77. For other material not included in previously mentioned collections, see, for example, Ali Melling, 'Wartime Opportunists: Ladies' Football and the First World War Factories', in J.A. Mangan (ed.), Militarism, Sport, Europe: War Without Weapons (London: Frank Cass, 2003), 120-141.

${ }^{32}$ See, for instance, Matthias Marschik, 'Offside: The Development of Women's Football in Austria', Occasional Papers in Football Studies 1, no. 2 (August 1998), 69-88; Jayne Caudwell, 'Women's Experiences of Sexuality Within Football Contexts: A Particular and Located Footballing Epistemology', Football Studies 5, no. 1 (April 2002), 24-45.

${ }^{33}$ Jean Williams Globalising Women's Football: Migration and Professionalisation 1971-2011 (Bern: Peter Lang, 2013); Sine Agergaard and Nina Clara Tiesler (eds.) Women, Soccer and Transnational Migration (London: Routledge, 2014).

${ }^{34}$ Kim Tofoletti and Peter Mewett (eds.) Sport and Its Female Fans (London: Routledge, 2014); Stacey Pope 'Female Football Fans and Gender Performance' in Eric Anderson and Jennifer Hargreaves (eds.) Routledge Handbook of Sport, Gender and Sexuality (London: Routledge, 2014) pp. 245-253.
} 
The papers in this collection, however, have their focus on developments related to women and football that occur outside the locus of established scholarship. In particular, the studies concentrate on the geographic locations of New Zealand, Australia and the USA, and, unique for such a collection, the papers cover all four major football codes. The investigations are also not limited to women playing football, but female spectators and coterie groups are also considered. In terms of variety, different methodological and theoretical approaches are adopted, and a range of time periods are covered, as outlined below.

Jennifer Curtin kicks-off the collection with reflections on women's engagement with rugby union in New Zealand, stretching her investigation back to some of the earliest newspaper references to female involvement in the code between 1870 and 1920. As she notes, a picture emerges. Women from both the lower and middle classes of New Zealand society clearly supported the game of rugby as spectators, supporters and fans. But the reception to this involvement was mixed, and sometimes seen as distinctly unsuitable. In addition, claims Curtin, women's involvement was often informal and localized, and it is this feature, she says, that helps to explain women's virtual invisibility in the histories of rugby union in New Zealand.

Barbara Cox and Richard Pringle, while also focusing on New Zealand, hone in on a different code and on two particular time periods. In their study, they draw heavily on the works of Michel Foucault to examine how women's bodies, exercise and motherhood impacted on the historical development of female soccer in New Zealand in 1921 and between 1973 and 1975. Employing Foucault's genealogical framework they not only analyze newspaper reports, and historical documents, but they conduct in-depth interviews to demonstrate how 
medical/scientific discourses both inhibited and aided the involvement of women in football. Their conclusion is that while medical knowledge was used to publically disqualify the legitimacy of the female footballer in 1921, the absence of such medical knowledge in the early 1970 s, combined with other factors, paved the way for the eventual 'normalization' of female football in New Zealand.

A more general overview of women's soccer in Australia is tackled by Roy Hay, Ian Syson and Greg Downes. They point out that women have fought to overcome active obstruction to their taking part in the sport and their paper provides an outline of the history of the game both nationally and in its international context. Making use of oral testimony, they attempt to capture the experience of some of the pioneers of the women's game and its modern exponents, along the way revealing some of the ways in which overt and covert discrimination still hampers appreciation of what these women have achieved.

In the penultimate paper in the collection, Andrew D. Linden mines his doctoral research to look at the contested space associated with women's American football in the 1970s. Scholarship on the 'women's movement' in the United States has grown in recent years, but as Linden acknowledges, this area has yet to fully incorporate women's athletic experiences. His paper, based on 13 interviews, brings together these two areas of analysis of women's experiences of playing professional football. His intent is not to force a feminist mantle on these women or to contest their own self-descriptions. Rather, he attempts to locate their experiences within the larger women's movement using the notion of 'contested space'. He convincingly argues that while women football players did not explicitly align with the feminist movement, they were a part of the larger revolution in women's social rank. 
Competitive matches of women's Australian Rules football have been played since 1915, when two workplace teams began a series of games in Perth, Western Australia, with the female code then diffusing east to South Australia and Victoria during the period of the Great War. ${ }^{35}$ While the women's game is about to undergo a revolution with the advent of a national league in 2017, Lisa Gye turns her attention off the field of play to examine female coteries in Australian Football League (AFL) clubs. She explains that the AFL has made extensive efforts in the past decade to ensure that Australian Rules football is seen as an inclusive culture that respects and acknowledges the presence of female supporters in its membership base. However, given that women have constituted a significant proportion of the football audience since the inception of the game in the mid-1800s, her view is that this show of support for women is somewhat belated and underpinned by other motivations. In fact, Gye's paper questions whether recent attempts to acknowledge women as an important constituent group in AFL football culture are genuinely aimed at making AFL club culture more inclusive of women. It remains to be seen how well the new embrace of women's football by the AFL meshes with, or contradicts, the old attitude displayed towards women's coterie groups. In any research agenda that emerges from such observations, international perspectives on the relationship of women with football, as partially revealed in this collection, will continue to be of value.

\section{Note on Contributors}

Jean Williams is Professor of Sports History and Culture at De Montfort University Leicester, England. Jean has written extensively on women's football, funded by both FIFA and UEFA.

\footnotetext{
${ }^{35}$ See, for example, Peter Burke, 'Patriot Games: Women's Football During the First World War in Australia', Football Studies 8, no. 2 (2005), 5-19, Rob Hess, 'Missing in Action? New Perspectives on the Origins and Diffusion of Women's Football in Australia During the Great War', The International Journal of the History of Sport 31, no. 18 (December 2014), 2326-2344, and Rob Hess, 'Women's Australian Football', in David Nadel and Graeme Ryan (eds), Sport in Victoria: A History (Melbourne: Ryan Publishing, 2015), 267-269.
} 
Her most recent book is A Contemporary History of Women's Sport: Part 1: Sporting Women, 1850-1960 (London: Routledge, 2014) and she is currently working on Send Her Victorious: A History of British Women Olympians (Manchester University Press).

Rob Hess is an Associate Professor in sport history associated with the College of Sport and Exercise Science and the Institute of Sport, Exercise and Active Living at Victoria University, Australia. He serves as the managing editor of The International Journal of the History of Sport. 